Terry D. Clark*

Creighton University

\title{
U.S. Foreign Policy in the Aftermath of the 2006 Congressional Elections: Neoconservatism and Its Opponents
}

\begin{abstract}
The terrorist attacks of 9/11 resulted in the Bush Administration (that of the forty third president of the United States) shifting U.S. foreign policy in a direction long urged by a group of intellectuals and policy advocates known as the Neoconservatives. Six years later, it is clear that the U.S. foreign policy community has rejected the Neoconservative argument without coming to consensus on an alternative paradigm. Hence, U.S. foreign policy is likely to be ad hoc in the near to mid-term, dealing with each newly emerging crisis and issue in isolation from others. Given this non-holistic approach, the United States will be forced to attempt to manage global affairs in reactive fashion, ceding the initiative to those states with clearer ideas of their national goals and interests. Among them will be China, Iran, and a newly re-assertive Russia
\end{abstract}

\section{Introduction}

It is generally conceded that the terrorist attacks of $9 / 11$ resulted in the Bush Administration shifting U.S. foreign policy in a direction long urged by a group of intellectuals and policy advocates known as the Neoconservatives. The group had criticized both the Bush Forty-One and Clinton administration throughout the decade of the 1990s for failing to properly assess the looming threats to the international system in the wake of the collapse of the Soviet Union and permitting U.S. military power to erode significantly. The shock of $9 / 11$ not only made the Neconservative case that the global order was much more fragile than thought, it left it with virtually no other competitor in the competition of ideas on how best to conceptualize the international system and organize an appropriate foreign policy.

Six years later, the mid-term Congressional elections would appear to have dealt a blow to the Neoconservative foreign policy that emerged as a response to 9/11. The 2006 elections swept the Republicans out of power in both

\footnotetext{
* Dr. Terry D. Clark is a Professor of Political Science and Director of the Graduate Program in International Relations. Address: Creighton University, Omaha NE 68178, Nebraska, USA, e-mail: tclark@creighton.edu
} 
houses of Congress and replaced them with a majority Democratic Party that, although not of one mind on how best to do so, was decidedly determined to bring about a change in U.S. foreign policy. The precipitating crisis accounting for the Republican defeat was the public perception that the Bush Administration had committed the country to a war in Iraq that was too costly in resources and lives. Strangely enough, however, the president's approval rating, which had long been dependent on the course of the war, was dealt its most serious blow by Hurricane Katrina, rather than the continued insurgency. While the public was increasingly weary of the war, the president had won the 2004 elections by appealing to the claim that his was the most competent to deal with the threat of terrorism. The Administration's slow reaction to Hurricane Katrina signaled ineptness and undermined the public's faith in the president's claim of competence. The result was a vote of no confidence in the president.

Hence, the Democrats were delivered an opportunity to govern without having made any definitive promises, apart from little more than a commitment to change. Furthermore, while they were much more united on what that might mean domestically, they were decidedly less so on foreign policy and the war in Iraq. While some called for an immediate pull out, others urged a phased pull out, and still others supported a pull back to blocking positions. The fissures within the Democrats' ranks assisted the president in overcoming both Congressional resistance and public disapproval to engage in a military surge in Iraq.

Despite this, it is clear that the president and the Republicans will have to shift their strategy in the run-up to the 2008 general elections. Failing to do so, they risk losing not only the White House but sustaining further dramatic losses in the Senate and House of Representatives. Since any fundamental change in strategy entails a rejection of the Neoconservative ideas that led to the strategy in the first instance, this necessarily requires that a new foreign policy paradigm be adopted. I argue in this paper that no new paradigm is available. Indeed, were there one, the Democrats would have been able to rally both their party and the public around it and forced President Bush to accede to their demands instead of engage in the surge operations within Iraq over summer 2007. I begin by reviewing the history of the emergence of the Neoconservative foreign policy paradigm. I then discuss the paradigm itself. I conclude with a consideration of the failed attempts of the effort to displace it. My thesis is that while it has been rejected politically, there is no intellectual commitment to a replacement. I conclude with a discussion of the consequences of this reality for U.S. foreign policy 


\section{U.S. Foreign Policy during the Cold War}

Nation-states need paradigms in order to achieve their foreign policy goals. While such paradigms do not define national interests, those same interests can not be achieved without a worldview that unites foreign policy elites, permits a sustained commitment to a course of action, and convinces the international system of the coherency and commitment to that course of action. Paradigms provide such worldviews.

During the Cold War, the United States' national interests were to assure the country's security by expanding free markets and encouraging democracy. The commitment to free market democracy was rooted in the wide spread perception in the West that World War II had been precipitated by expansionist authoritarian states that had seized upon the misery caused by economic hardship. The best way to guard against dictatorships was to encourage development, which was best done by open, liberal market economies. Building upon this notion, George F. Kennan penned a famous essay ${ }^{1}$ arguing that the Soviet Union, like all dictatorships, was inherently expansionist. While it preyed upon the economic fears and misery of its population by promising a restoration of economic well-being, it could not deliver on these promises owing to the serious distortions and inefficiency inherent in the Soviet planned economic system. Hence, the communist ruling elites had to resort to finding an external enemy to blame for the system's inability to deliver on its economic promises, which in turn required some evidence of progress against the external enemy. This could best be demonstrated by expansion abroad. Kennan argued that if the Soviet Union could be contained within its borders, the population would ultimately tire of the regime's failure, and the political system would collapse from within.

Kennan's ideas united U.S. foreign policy elites around the paradigm of containment for most of the Cold War. Indeed, despite severe losses sustained in wars in both Korea and Vietnam, presidents and major political figures in the country's foreign policy community remained largely committed to it. The power and intellectual appeal of the paradigm lay in its elegance and parsimony. Not only did it paint a global system completely defined by a struggle between great contending powers, it was further embedded within a paradigm that raised core U.S. interests in free markets and democracies to the level of virtues. It was for this very reason that East and East Central European publics watched incredulously as then President George Herbert Walker Bush (FortyOne) appealed to legislatures in break away Soviet republic to stay within the Soviet Union. Containment had proven its worth as a paradigm guiding U.S. foreign policy. So much so, that the U.S. did not wish to jettison it. Instead, it hoped to continue managing the global system in a bipolar standoff with the Soviet Union in which the latter would be seriously weakened and free markets and democracy would be pre-eminent.

\footnotetext{
${ }^{1}$ X [George F. Kennan], "Sources of Soviet Conduct”, Foreign Affairs, July 1947.
} 
Such was not to be. Indeed, even had the Soviet Union been able to maintain the internal cohesion necessary to such a role, the collapse of its commitment to the socialist bloc meant the end of the international system as it had been. A new paradigm would be needed for this new system, but none was immediately available. This was most evident in President Bush's (FortyOne) National Security Strategy (NSS) issued in the wake of the collapse of the Soviet Union. Titled simply "engagement," it argued for no more than that the United States should remain committed to helping manage the global order. The short document was more a plea than a strategy. Indeed, its target appeared to be domestic, which is not at all surprising considering that the American public had tuned foreign policy out and were fully engaged in a discussion in how best to spend the so-called "peace dividend." The biggest problem for the administration was that it lacked an organizing concept of the global order in the absence of the Soviet Union, as a consequence of which it was unable to focus on existent threats to that as yet undefined order. Hence, it merely called for staying engaged in order to build a "new world order."

\section{The Era of Globalization}

Two ideas capable of serving as an organizing concept and around which the U.S. might fashion a foreign policy dominated intellectual thinking in the wake of the collapse of the Soviet Union: Francis Fukuyama's " End of History" and Samuel P. Huntington's "Clash of Civilizations." ${ }^{2}$ Fukuyama was far and away the more optimistic of the two. His thesis was that communism was the last major competitor to free market democracy, and that its collapse signaled the end of the struggle over grand ideas. While rogue states would continue to struggle against this reality, no other option was available to the international community. Hence, while inter-state conflict would persist, it would no longer pit powerful states in contests over ideals of human organization and governance. Furthermore, since the stakes would be lower, the likelihood of nuclear exchange or total war was greatly diminished, a fact which would make global governance and conflict management easier.

In contrast to Fukuyama's argument that core U.S. national interests had emerged at the end of the twentieth century as the recognized pre-eminent set of global interests, Huntington contended that the great conflicts of the future would be organized along civilizational lines roughly defined by great religious systems. Largely shorn of their religious content, these systems would nonetheless define ideals. Hence, instead of Fukuyama's universalism, Huntington saw fragmentation. At the heart of most civilizations stood a great power that policed the other states and in so doing provided the civilization

\footnotetext{
${ }^{2}$ Fukuyama F., "The End of History?", National Interest 16, 1989, p. 3-18; Huntington S. P., The Clash of Civilizations and the Remaking of World Order, Simon \& Schuster, 1996
} 
with a center of mass that permitted it to play a role in global governance, which essentially amounted to an international balance of power system. The core states of each civilization not only managed their own regions, but they jointly managed international conflict by engaging in fluid alliance behavior, bargaining, and posturing. This Morgenthau-like ${ }^{3}$ behavior on the part of the core states would occur in two sets of regions: those within civilizations without a core state and those along fault lines between civilizations. The former would be conflict-ridden as states engaged in intra-civilizational rivalries in order to seize the position as the core state. The latter would induce inter-civilizational conflict as a consequence of the uncertainty of its status in a system of states defined by civilizations.

While Huntington's realist notions provided much gist for debate, Fukuyama's idealistic argument offered an easier marriage with U.S. foreign policy thinking. Not only did it universalize U.S. national interests, but it reinforced the view that the United States had emerged in the position of a global hegemon in the wake of the collapse of the Soviet Union. Hence, the "American Moment" had arrived, but what was to be done? Fukuyama gave voice to its arrival, but did not provide a guide to how best to seize upon the opportunity to shape the international system.

That role increasingly came to be filled over the course of the 1990s by globalization. While there was no defining article or moment as there had been during the Cold War with Kennan's article on containment, elites in the foreign policy community slowly converged on globalization as an organizing idea.

Globalization's appeal lay in its claim that the processes by which countries adopted liberal markets and democratic governance systems were inter-linked and in the rational interest of all states. In effect, the process was virtually on "auto-pilot," which meant that management functions were reduced to oversight and facilitation and the need to resort to military force was greatly decreased.

The essential argument of globalization was that all countries wanted to prosper economically and that the only way to do so was to open up their markets to global competition. Failing to do so, they would become impoverished. Opening of domestic markets to domestic competition came attached with requirements for transparency, reigning in of corruption and bureaucratic interference with market operations, and protection for investors, without which global capital would shy away. These reforms were anti-authoritarian in nature. Furthermore, the opening of a country's borders to global capital investment would necessarily subject it to universal ideals on human rights, to include democracy. In a relatively short period of time, all of these forces would ultimately impress themselves upon the social system and lead to demands for political change. The regime would capitulate or risk losing the economic gains that had been achieved.

\footnotetext{
${ }^{3}$ Morgenthau H. J., Power among Nations: The Struggle for Power and Peace, 1985.
} 
While Samuel Huntington contended that the cultural norms of distinctly non-western civilizations would permit countries to open their borders to foreign investment and trade while simultaneously rejecting western values, his argument did not receive widespread acceptance among U.S. foreign policy elites who found the idealism of globalization far more appealing. This was clearly evident in Bill Clinton's National Security Strategy (NSS), which was ten times larger than that of George Herbert Walker Bush and appropriately titled "engagement and enlargement." Clinton's NSS not only called on the U.S. to remain engaged in the international system but to work actively to promote both international trade and democracy.

The influence of globalization was also evident in the specific foreign policy approaches in which the Clinton Administration engaged. The administration committed itself to engagement with China in order to bring it into the web of international regimes that would open it up to economic, social, and political change; and in Eastern and East Central Europe, the administration supported rapid privatization and marketization, arguing that this would lead to the emergence of a middle class that would establish the social base for democracy. The approach, which became known as the Washington Consensus, became the norm in International Monetary Fund restructuring programs in Latin America as well as in the wake of the Asian Crisis.

The rising interest in the democratic peace hypothesis further fueled the impetus to export democratic values. As Kissinger points out, the idea that democracies do not make war against each other has been a staple of American idealism informing U.S. foreign policy since at least the time of Woodrow Wilson ${ }^{4}$ In a paper in which they attempted to challenge this quintessentially American ideal, Small and Singer ${ }^{5}$ instead catalyzed renewed interest in it. Scholarship on the democratic peace comprised one of the most expansive research agenda of the 1990s and 2000s and helped to further establish the conventional wisdom that peace could be achieved by spreading American values, and democracy in particular, by liberalizing national economies across the globe.

\section{The Neoconservative Whimper}

Hence, globalization assumed hegemony status in U.S. foreign policy thinking during the 1990s, as its intellectual opponents were increasingly marginalized. While Huntington's "Clash of Civilization" was read and discussed, its influence amounted to little, and the writings of others were largely ignored. That was certainly the case of scholars laying the basis over the course of the decade of the nineties for what would ultimately become known as Neoconservatism.

\footnotetext{
${ }^{4}$ Kissinger H., Diplomacy, New York: Simon \& Schuster, 1994.

${ }^{5}$ Small M., Singer J. D., "The War Proneness of Democratic Regimes, 1816-1965”, Jerusalem Journal of International Relations 1, 1976, p. 50-69.
} 
This relatively small group of intellectuals agreed with the general thesis of globalization that U.S. values had been, and were being, widely adopted across the international system in the wake of the collapse of the Soviet Union. However, they contended that assuring that the process would continue would require active involvement by the United States to "shape" the outcomes. In their view, the United States was instead passively permitting events to unfold without so much as an attempt to create something new ${ }^{6}$. In the absence of a plan or strategy, the opportunity to secure an international order reflecting and supporting U.S. national interests was being squandered ${ }^{7}$. Furthermore, weak American leadership was leading many allies to conclude that the U.S. could not be counted on. This in turn fueled efforts to find alternatives to U.S. leadership in global affairs, a trend that would deny the country the ability to shape the international system in accordance with its own values and interests ${ }^{8}$.

The Neoconservatives were particularly concerned with rogue states that challenged the international order. These dictatorships included Saddam Hussein's Iraq and North Korea. The solution as the Neoconservatives saw it was to adopt a commitment to "regime change" which would deter such behavior both on the part of these states and emerging powers such as China".

Contrary to the assertions of some, the Neoconservatives were not arguing against globalization. (See, for example, Paul Wolfowitz's argument for maintaining trade with China ${ }^{10}$.) In general, they agreed with the powerful allure that open markets represented. Furthermore, increasing international trade and investment flows did indeed bring with it pressures for political liberalization and democratization. Like Huntington, the Neoconservatives were questioning whether globalization must inevitably follow a benevolent course. The promise of economic well-being alone might not be sufficient to secure the international order. Dictators might not find that sufficient to deter them from disruptive behavior. In those instances in which their behavior threatened U.S. interests or the international commitment to free market democracy, the U.S. had to be ready to use force if necessary, and to do so despite the inevitable charges of heavy-handedness and arrogance that must assuredly follow the use of force. Failing to do so, the international system would be challenged and ultimately undone by a consortium of rogue states bent on ending not only U.S. hegemony but that of free market democracy as well.

\footnotetext{
${ }^{6}$ Ceaser J.W., "The Great Divide: American Internationalism and Its Opponents” in Kagan R., Kristol W., eds., Present Dangers: Crisis and Opportunities in American Foreign and Defense Policy, Encounter Books, 2000, p. 25-43.

${ }^{7}$ Kristol W., Kagan R., "Introduction: National Interest and Global Responsibility” in Kagan R., Kristol W., eds., Present Dangers: Crisis and Opportunities in American Foreign and Defense Policy, Encounter Books, 2000, p. 3-24.

${ }^{8}$ Gedmin J., "Europe and NATO: Saving the Alliance" in Kagan R., Kristol W., eds., Present Dangers: Crisis and Opportunities in American Foreign and Defense Policy, Encounter Books, 2000, p. 179-196.

${ }^{9}$ Kristol, Kagan (note 6).

${ }^{10}$ Wolfowitz P., "Statesmanship in the New Century" in Kagan R., Kristol W., eds., Present Dangers:

Crisis and Opportunities in American Foreign and Defense Policy, Encounter Books, 2000, p. 324-332.
} 
This would require that the U.S. commit to acting pro-actively to protect the international system, which it dominated. The justification from the Neoconservative perspective was transparent. A world in which the United States was pre-eminent was necessarily a more just one. Furthermore, assuring the pre-eminence of American values constituted the national interest ${ }^{11}$.

The Neoconservatives understood that they were departing from traditional American conservative positions on the role of the United States in the international system. Conservatives had either been isolationist or realist ${ }^{12}$. The former was the older of the two and deeply rooted in an American sense of exceptionalism ${ }^{13}$. Judging that the international system would be perpetually hostile to American democracy, George Washington, upon leaving office, advised his fellow citizens to avoid "foreign entanglements." While Woodrow Wilson had been unable to dislodge this commitment to isolation during the inter-war period; the country emerged as a global power in the aftermath of World War II and the Cold War subsequently left it with no other options than to engage or submit to Soviet global domination. Conservatives responded by reluctantly embracing a realist approach intended to secure U.S. interests without being constrained by moral or ethical considerations.

On the other hand, since the time of Woodrow Wilson, the American political left had argued for engagement in international affairs in order to spread and secure U.S. values. The liberal advocates of an active U.S. foreign policy dominated political science departments during the inter-war period and established the idealist paradigm at the center of the discipline. The focus on values placed the Neoconservatives closer to the idealist tradition than either conservative tradition ${ }^{14}$. Indeed, many of them strongly criticized the Nixon Administration for sacrificing American ideals in order to placate China. Similarly, others castigated Clinton for supporting Yeltsin's 1993 coup against the democratically elected legislature ${ }^{15}$. This fundamental departure from the conservative approach in favor of a more idealist foreign policy earned the movement the prefix "neo."

\footnotetext{
${ }^{11}$ Kristol, Kagan, (note 7), p. 24.

${ }^{12}$ Ceaser, (note 6).

${ }^{13}$ Gaddis J. L., Surprise, Security and the American Experience, Harvard University Press, 2004.

${ }^{14}$ See: Bennett W. J., "Morality, Character and American Foreign Policy" in R Kagan R., Kristol W., eds., Present Dangers: Crisis and Opportunities in American Foreign and Defense Policy, Encounter Books, 2000, p. 289-306.

${ }^{15}$ Rodman P.W., "Russia: The Challenge of a Failing Power" in Kagan R., Kristol W., eds., Present Dangers: Crisis and Opportunities in American Foreign and Defense Policy, Encounter Books, 2000, p. 75-98.
} 


\section{The Neoconservative Moment}

That the Neoconservative argument fell on deaf ears did not owe to its call to harness U.S. foreign policy to the country's values ${ }^{16}$ (see Bennett, 2000), indeed that was the part of the paradigm that most appealed to American foreign policy thinkers. Rather, the emphasis on the exercise of power to achieve U.S. national interests was worrisome since there were no obvious threats. Furthermore, the use of military force appeared to be an unnecessary cost if the ends could be achieved in a more benign fashion, as promised by globalization theory, simply by relying on the logic of global market forces. Finally, there appeared to be no rationale for the use of force as long as the international system was fundamentally stable, and it most certainly appeared to be stable. That is until 9/11.

The blow that $9 / 11$ delivered against the U.S. foreign policy community's faith in the stability of the international system can not be understated. Indeed, al Qaeda was practicing the art of modern war by unconventional means. The Vietnam War marked the end of an era in warfare. Since the French Revolution, armies had fought wars of attrition. The increasing power of weapons of mass destruction beginning with the repeating rifle and extending through to the machine gun, artillery, the tank, and military aviation made the cost in lives of fighting such wars staggering. One of the lessons of Vietnam was that the loss of life involved in wars of attrition could itself result in defeat, even for the side that not only could suffer greater losses but was actually suffering fewer losses. In the wake of the defeat in Vietnam, the U.S. military developed a fundamentally new concept of war. Instead of winning wars by attrition, the U.S. military redesigned its doctrine, tactics, equipment, and training to win wars by targeting the enemy's strategic nodes (those centers essential for the enemy to continue fighting, to include command and control and the materiel base).

The planners of $9 / 11$ targeted the very center of U.S. power, its economic base in New York City. Evidence of the degree to which they almost succeeded is provided by the fact that the attack shut down the New York Stock Exchange. Indeed, the shock that the attack delivered resulted in serious decapitalization (the Dow Jones Industrial Average did not recover its pre-9/11 levels for several years) and a global recession. In a very real sense, the collapse of globalization as a paradigm driving U.S. foreign policy was among the losses suffered on 9/11. It simply could not account for such a serious blow to the international system, and it offered no guide to a response.

The situation in which the U.S. found itself in the wake of the terrorist attacks of 9/11 demanded a new foreign policy paradigm. Neoconservatism offered itself. The fact that several Neoconservatives occupied positions of responsibility within the Bush Administration most certainly influenced the decision to adopt the paradigm. However, it would be a serious mistake not to

\footnotetext{
${ }^{16}$ Bennett, (note 14).
} 
acknowledge the intellectual appeal of its parsimony and elegance. In a moment of crisis when a guide to action was needed, these qualities were decisive.

Increasing Neoconservatism's appeal was that it held to the basic core of globalization. It merely added the notion that dictators at the head of rogue states bent on destabilizing the international system could not be ignored. Rather, they had to be dealt with. Adoption of the Neoconservative paradigm was therefore a relatively easy matter since it did not involve jettisoning approaches to a wide range of issues and states. The only changes that would be required would be a policy of regime change toward rogue states that refused to acquiesce to international norms. Where the threat they posed was deemed sufficient and in those cases in which diplomatic or economic pressure were not likely to work, resort might be made to military force.

The Neoconservative paradigm, like most paradigms of the international system - to include idealism, realism, and globalization - is state-centric. That is, it assumes that the primary actors in the international system are states. Other actors act through states or their actions are informed by those of states. Hence, the immediate response to al Qaeda, a transnational terrorist organization, was to deny it sanctuary, beginning in Afghanistan. Subsequently, the U.S. engaged in a mix of financial, economic, diplomatic, covert intelligence, and military operations to shut down al Qaeda in other countries across the globe.

The adoption of Neoconservatism by the Bush Administration was formalized in the National Security Strategy issued on September 17, 2002. The document's preamble expressed the essence of the Neoconservative argument. It stated that the U.S. held unprecedented military, political, and economic power within the international system. It would eschew the temptation to use this power for unilateral advantage and instead seize the opportunity to extend freedom, a universal human value, to all citizens of the globe by spreading free market democracy. The United States would work with less developed nationstates to overcome poverty, which provided the soil within which dictatorship and terrorist organizations bent on undermining the prosperity and liberty associated with free market democracy could take root.

The main body of Bush's NSS further emphasized these same points. The opening chapter, "Overview of America's International Strategy," elucidated the idealist vision contained in Neoconservative writings that the U.S. could make the world a better place. The chapter began with the assertion that the United States had emerged from the Cold War as the most powerful country in the world. It then committed the country to use its position to shape the global order by spreading prosperity through free markets and liberty through democracy. Chapter two, which contained a speech by President Bush at the United States Military Academy at West Point, New York, on June 1, 2002, ${ }^{17}$ was an unambiguous assertion that these constitute universal human values and goals. Several of the remaining chapters might just as easily have been associated with

\footnotetext{
${ }^{17}$ The speech was the first public acknowledgement that the administration would commit itself to a Neoconservative foreign policy.
} 
globalization as with the ideas of the Neoconservatives. This was particularly the case for chapters six and seven, which addressed increasing international trade and prosperity, and spreading democracy. What distinguished the 2002 NSS is the emphasis placed on dealing with rogue states, particularly those that had the potential for developing and using weapons of mass destruction. Chapter five, "Prevent Our Enemies from Threatening Us, Our Allies, and Our Friends with Weapons of Mass Destruction" was a critical chapter in developing this theme. The chapter took pains to point out that these states opposed liberty and freedom. It went on to assert that they stood behind international terrorism. Furthermore, their access to technology gave them the potential to develop weapons capable of threatening the international system and the values that it sustained. Hence, the United States could no longer afford to simply react to their initiatives. Instead, it would have to assume a more pro-active posture and engage in pre-emptive strikes when and where necessary.

The concerns the NSS expressed about rogue states and their potential for threatening regional and global security reflected those of prominent Neoconservatives in the 1990s. Among their particular targets was Iraq. The general view was that Bush Forty-One had failed by not removing Saddam Hussein from power. Furthermore, they challenged the assertion that Saddam's regime was essential to the balance of power in the Middle East ${ }^{18}$. To the contrary, the possibility that Saddam would develop weapons of mass destruction was the major threat to regional and global stability ${ }^{19}$. Therefore, he had to be removed.

\section{The Neoconservative Quagmire}

The decision to invade Iraq in order to impose regime change on the Middle Eastern country in retrospect dealt what appears to be a fatal blow to the dominant position of the Neoconservative paradigm in U.S. foreign policy. Indeed, given the failure to find significant caches of weapons of mass destruction, the inability to secure the peace after toppling Saddam Hussein, and the potential for the rapid spread of Iranian influence and power throughout the Gulf region once the U.S. withdraws, the Neoconservatives and their ideas have been roundly rejected by all but their most ardent proponents.

As many have observed, the rejection of Neoconservatism owes as much as anything to the ad hoc nature of the war in Iraq. The decision to invade was premised on two arguments. First, Saddam Hussein's nuclear, biological, and

\footnotetext{
${ }^{18}$ Perle R. N., "Iraq: Saddam Unbound" in R Kagan R., Kristol W., eds., Present Dangers: Crisis and Opportunities in American Foreign and Defense Policy, Encounter Books, 2000, p. 99-110.

${ }^{19}$ Abrams E., "Israel and the "Peace Process" in Kagan R., Kristol W., eds., Present Dangers: Crisis and Opportunities in American Foreign and Defense Policy, Encounter Books, 2000, p. 221-240; Also see: Perle, (note 17).
} 
chemical weapons programs together with a commitment to unconventional warfare forced upon him by the logic of the assymetrical power relationship with the United States, meant that these weapons would likely end up in the hands of international terrorists, acting as clients of the Iraqi dictator. Second, the Saddam Hussein dictatorship represented an affront to prosperity and democratic norms laying at the core of the U.S.-led international system. Once it was discovered that Iraq's programs for the development of weapons of mass destruction were far less robust than thought, the first argument quickly unraveled. The second argument was never enough for the Neoconservatives to justify the use of military force to impose regime change. In fact, by their own arguments, force would only be used if the dictatorship threatened the stability of the international order. Otherwise, resort would be made to economic sanctions and the "demonstration effect" of freedom and prosperity in neighboring states to bring the dictatorship to an end. Hence, the unraveling of the first argument left little to no justification for the invasion from the Neoconservative position, at least as the administration framed the issues involved in the decision to undertake the effort.

This need was not to have been the case. In fact, there was a thoroughly logical justification for the war in Iraq. Both Neoconservativism and globalization argue that dictators shut their countries off from international trade and investment capital and in so doing condemn them to poverty. Unlike globalization, which assumes that either internal pressure from popular discontent or the recognition that their own economic interests are being damaged will eventually convince these dictators to open their country's markets, Neoconservatism argues that, in some instances, they may choose instead to mount a challenge to the international system. The Bush Administration chose to truncate the argument at this point and simply contend that $9 / 11$ demonstrated that they could do so using terrorism as a proxy, and that weapons of mass destruction would radically increase the threat that they would pose. Since Iraq had a program for developing such weapons, Saddam Hussein would have to be removed from power.

What the administration and its Neoconservative advisers might have given further consideration to is the mechanism by which dictators remain in power given popular discontent. If they do not manage to divert that discontent, then the globalization thesis is a compelling one. Dictatorships need only be contained until they eventually implode. This was after all what Kennan had correctly predicted would happen in the Soviet Union. However, as the Neoconservatives had pointed out, a decade of containing Iraq with economic sanctions and no-fly zones had resulted in the country increasingly destabilizing the Middle East ${ }^{20}$. This owed to the continuing Israeli-Palestinian conflict, which Saddam Hussein had a vested interest. As long as the conflict continued smoldering, then he could paint the United States as the chief supporter of the Jewish state and himself as the leader of Arab cause to erase that state from the political map.

${ }^{20}$ Perle (note 18). 
Indeed, it could be argued that other dictatorships across the Middle East also project their population's discontent from the regime onto Israel. Using their economic and political influence over the Palestinian leadership, they essentially veto any meaningful peace deal in order to assure the IsraeliPalestinian conflict continues to fester unabated, providing them with a source upon which to focus their populations' frustrations. Imposing regime change on Iraq would not only remove a major bloc to the Israeli-Palestinian conflict, it would send a clear message to other dictatorships, such as Iran, Syria, and Saudi Arabia. In essence, Iraq was a necessary step to removing the Israeli-Palestinian as an issue sustaining anti-libertarian regimes. The remaining states in the region, to include Iran, are more thoroughly integrated in to the international trade system. Hence, they would have little other alternative than to engage in political and economic reform or face internal instability.

This more nuanced argument and the strategy that it calls for are far more complex than that which the Bush Administration seized upon in the wake of $9 / 11$ that ultimately led to the war in Iraq. Its adoption might well have resulted in the decision not to invade Iraq given the higher stakes and the more realistic assessment of the time and resources that the effort would require. At a minimum, it would have drawn attention to the wider implications of the war, at least in regards to the potential for conflict with Iran and difficulties with Syria and Saudi Arabia. Had it been adopted, however, both the logic of the strategy and the estimates of what it would cost would have been clearer. Furthermore, the fact that no weapons of mass destruction were found would have been irrelevant.

For whatever reason, the Bush Administration failed to articulate or choose this more integrated, long-term strategy for bringing peace to the Middle East and denying terrorists a cause or a base of support in the region. The consequence of the war in Iraq has been the unraveling of the Bush Administration foreign policy and the political rejection of Neoconservatism by U.S. foreign policy elites. Nonetheless, while Neoconservatism has been rejected as a failed strategy, the problem is that there is no alternative readily available to replace it. Hence, its rejection is based on an assessment of failure in a given instance, but not an assessment that it is comparatively inferior to any alternative approach. This will likely prove highly problematic for U.S. foreign policy in the near to short-term.

\section{The Collapse of Neoconservatism: Implications for U.S. Foreign Policy}

While the critiques of Neoconservatism have been legion, no intellectually parsimonious or forceful alternative has yet been offered. Former National 
Security Adviser to President Jimmy Carter, Zbigniew Brzezinski called for a return to globalization as the guiding idea behind U.S. foreign policy ${ }^{21}$. Starting from the premise that any hegemon will inevitably elicit opposition for no other reason than that it is a hegemon, Brzezinski contends that the U.S. will be compelled to accept some degree of international instability. In his view, Iraq under Saddam Hussein presented an acceptable level of instability. There are, in fact, other regions where the potential for instability is unacceptable. To manage them effectively, the United States must work multi-laterally in conjunction with its allies, building upon and expanding a shared global community of interests.

However, Brzezinski admits that the United States may be compelled on occasion to act unilaterally ${ }^{22}$. Hence, his primary critique appears to be reducable to a single dimension: the war in Iraq was a mistake. The contention is based on little more than a higher threshold for determining "threats" to the international system. In Brzezinski's view, the Bush Administration seeks "total" security. He urges the acceptance of an acceptable level of insecurity. In essence, he does not offer an innovative departure.

Joseph S. Nye, Jr. had been among the more persistent critics of Neoconservatism. Like Brzezinski, he argues for a return to globalization as the guiding idea behind U.S. foreign policy. In his view, no dictator can offer a serious threat to the international system. The true threat is that the arrogant use and abuse of U.S. power will persuade a critical mass of the globe's citizens to band together to oppose the hegemon. Hence, the U.S. must rely more on soft power, that is the persuasive force of its ideals and values, not the hard power of its military. It is soft power that will blunt the efforts of dictators to foment discord and challenge global stability. The United States can markedly increase its soft power by putting its resources to the task of achieving global interests, vice national interests, and working for a socially just economic and political order ${ }^{23}$.

Both Brzezinski and Nye contend that the turn to Neoconservatism was rooted in an over-estimation of the degree to which the terrorist attacks of 9/11 destabilized the international system. Indeed, the critiques of Neoconservatism all share the same fundamental faith in the stability of the system, the stability of which is assured by U.S. economic and political power. In their view, the real threat to system stability is U.S. over-reaction to events, resulting in the imprudent use of force. In essence, they are contending for a more pragmatic foreign policy, shorn of the idealism of the Neoconservatives, for whom U.S. hegemony offers the opportunity to shape the globe to reflect U.S. values, to include liberty and freedom. Brzezinski, in particular, focuses on achieving no higher goal than a well-managed international system. Indeed, this is the crux

\footnotetext{
${ }^{21}$ Brzezinski Z., The Choice: Global Domination or Global Leadership, Basic Books, 2004.

${ }^{22}$ Ibidem.

${ }^{23}$ Nye J. S., Jr.,. The Paradox of American Power: Why the World's only Superpower Can't Go It Alone, Oxford University Press, 2002.
} 
of the difference between the Neoconservatives and their critics. The former wish to shape outcomes, the latter are willing to accept less, their primary goal is being stability.

While Neoconservatism's allure owes much to its quintessentially American idealism, its elegance and parsimony should not be over looked. Indeed, not only are the arguments of intellectual opponents such as Brzezinski and Nye less idealistic, they are also simply too burdensome to be of use. This is demonstrated by the three year Princeton Project on National Security to forge a bipartisan agreement on a paradigm to guide U.S. foreign policy. Attempting to harness some of the country's finest foreign policy minds to the task of writing a new George Kennan-like "X article," the project's final report confesses that the group was not able to do $\mathrm{so}^{24}$. In fact, the report argues, the complexity of the international system does not permit U.S. foreign policy to be based on a single organizing principle ${ }^{25}$. Instead, the U.S. must address multiple threats, it must be prepared to use a mix of hard and soft power, it must pursue its interests in collaboration with its allies, it must act on the basis of its values not its fears, it must address the internal dynamics of states not just their external relations, and it must adapt to the information age. While it is difficult to challenge any item on this list, it is no more than that, a list. Absent an organizing principle, the committee could not be expected to come with anything better.

Indeed, this is the problem of the moment. The United States foreign policy community has clearly rejected the Bush foreign policy and the Neoconservative frame work that underlies it. Furthermore, it embraces the core ideas of globalization: the fact of U.S. global hegemony and the benign effects of free markets and democracy. Any U.S. foreign policy will be founded on these assumptions. What is not clear is what are the threats to the system and how are they to be addressed? Absent an answer to these questions, United States foreign policy is likely to be ad hoc, dealing with each newly emerging crisis and issue in isolation from others. Given this non-holistic approach, the United States will be forced to attempt to manage global affairs in reactive fashion. Hence, it will necessarily surrender the initiative to those states with clearer ideas of their national goals and interests. Among them will be China, Iran, and a newly reassertive Russia.

\footnotetext{
${ }^{24}$ Ikenberry G. J., Slaughter A. M., Forging a World of Liberty under Law: U.S. National Security in the $21^{s t}$ Century, The Princeton Project Papers, The Woodrow Wilson School of Public and International Affairs, Princeton University, 2006, p. 4, 58.

${ }^{25}$ Ibidem, p. 13.
} 


\section{References}

1. Abrams E., "Israel and the 'Peace Process"” in Kagan R., Kristol W., eds., Present Dangers: Crisis and Opportunities in American Foreign and Defense Policy, Encounter Books, 2000, p. 221-240.

2. Bennett W.J., "Morality, Character and American Foreign Policy" in Kagan R., Kristol W., eds., Present Dangers: Crisis and Opportunities in American Foreign and Defense Policy, Encounter Books, 2000, p.. 289-306

3. Brzezinski Z., The Choice: Global Domination or Global Leadership. Basic Books, 2004

4. Ceaser J.W., "The Great Divide: American Internationalism and Its Opponents" in Kagan R., Kristol W., eds., Present Dangers: Crisis and Opportunities in American Foreign and Defense Policy, Encounter Books, 2000, p. 25-43.

5. Fukuyama F., "The End of History?” National Interest, 1989, 16, 3-18.

6. Gaddis J.L., Surprise, Security, and the American Experience. Harvard University Press, 2004.

7. Gedmin J., "Europe and NATO: Saving the Alliance" in Kagan R., Kristol W., eds., Present Dangers: Crisis and Opportunities in American Foreign and Defense Policy, Encounter Books, 2000, p. 179-196.

8. Huntington S.P., The Clash of Civilizations and the Remaking of World Order. Simon \& Schuster, 1996

9. Ikenberry, G.J., Slaughter A-M. Forging a World of Liberty under Law: U.S. National Security in the $21^{\text {st }}$ Century, Princeton Project Papers, Woodrow Wilson School of Public and International Affairs, Princeton University, 2006.

10. Kissinger, H. Diplomacy. New York: Simon \& Schuster, 1994

11. Kristol W., Kagan R., "Introduction: National Interest and Global Responsibility" in Kagan R., Kristol W., eds., Present Dangers: Crisis and Opportunities in American Foreign and Defense Policy, Encounter Books, 2000, p. 3-24.

12. Morgenthau H.J. Power among Nations: The Struggle for Power and Peace, 1985

13. Nye J.S, Jr., The Paradox of American Power: Why the World's only Superpower Can't Go It Alone. Oxford University Press 2002.

14. Perle R.N., "Iraq: Saddam Unbound" in Kagan R., Kristol W., eds., Present Dangers: Crisis and Opportunities in American Foreign and Defense Policy, Encounter Books, 2000, p. 99-110.

15. Rodman P.W., "Russia: The Challenge of a Failing Power" in Kagan R., Kristol W., eds., Present Dangers: Crisis and Opportunities in American Foreign and Defense Policy, Encounter Books, 2000, p.75-98.

16. Small M., Singer J. D., "The War Proneness of Democratic Regimes, 1816-1965." Jerusalem Journal of International Relations 1976, 1, 50-69.

17. Wolfowitz P., "Statesmanship in the New Century" in Kagan R., Kristol W., eds., Present Dangers: Crisis and Opportunities in American Foreign and Defense Policy, Encounter Books, 2000, p. 307-336.

18. X [George F. Kennan], "Sources of Soviet Conduct", Foreign Affairs, July 1947. 